\title{
ANALISIS PELAKSANAAN PEMBELAJARAN JARAK JAUH BERBASIS E-LEARNING PADA MASA PANDEMI COVID-19 MAHASISWA DI JURUSAN PENDIDIKAN IPS FKIP UNIVERSITAS RIAU
}

\author{
Indra Primahardani ${ }^{1 *}$, Dedi Futra ${ }^{2}$, Riki Apriyandi Putra ${ }^{3}$ \\ ${ }^{1}$ Program Studi Pendidikan Pancasila dan Kewarganegaraan, Fakultas Keguruan \\ dan IImu Pendidikan, Universitas Riau, Pekanbaru, Indonesia \\ ${ }^{2}$ Program Studi Pendidikan Kimia, Fakultas Keguruan dan IImu Pendidikan, \\ Universitas Riau, Pekanbaru, Indonesia \\ ${ }^{3}$ Program Studi Pendidikan Biologi, Fakultas Keguruan dan IImu Pendidikan, \\ Universitas Riau, Pekanbaru, Indonesia \\ *indraprimahardani@lecturer.unri.ac.id
}

\begin{abstract}
This study aims to describe and analyze about: forms of e-learning-based distance learning activities carried out at the Department of Social Studies FKIP Riau. This type of research is descriptive qualitative research. The data to be collected is ordinal data, which comes from the results of e-questionnaires(google form). The data collected is summative response scale, using a modified Likert scale with 3 answer options. Student responses are organized based on 3 levels of Likert Scale: 1 = Yes; 2 = No; 3 = Hesitation. The data obtained is then analyzed through a descriptive statistical analysis of percentages. The results showed that the form of implementation of distance learning activities carried out in the department of Social Sciences FKIP Riau University refers to the indicators of distance learning, namely: clear learning objectives, relevant to the needs, quality of education, efficient and effectiveness of the program, equality and expansion of learning opportunities, independence, integration and sustainability.
\end{abstract}

Keywords: e-learning; pandemic; pembelajaran jarak jauh; IPS.

\section{PENDAHULUAN}

Fakultas Keguruan dan IImu Pendidikan (FKIP) Universitas Riau merupakan suatu Lembaga Pendidikan yang terus berupaya menghasilkan lulusan-lulusan terbaik, bermutu, bermartabat serta berdaya saing dalam mutu pendidikan nasional maupun internasional. Hal ini tentu sejalan dengan terus berkembangnya pengetahuan dibidang teknologi, informasi dan komunikasi yang memberikan 
manfaat serta perubahan yang sangat besar dalam kemajuan sistem pendidikan baik di tingkat lokal, nasional maupun di tingkat internasional.

Berbagai jenis metode pembelajaran terus mengalami perkembangan. Bentuk perkembangan tersebut diantaranya berupa perkembangan metode pembelajaran yang menggunakan Teknologi Informasi dan Komunikasi (TIK). Proses pemanfaatan teknologi pada pembelajaran biasa disebut dengan pembelajaran elektronik atau e-learning. Inovasi pembelajaran berbasis elearning memberikan kontribusi yang sangat luas dimana kegiatan pembelajaran tidak terbatas pada uraian atau penjelasan guru semata, namun juga dapat memberikan visualisasi dalam berbagai macam format yang lebih interaktif dan bersifat dinamis, sehingga pembelajaran dengan metode e-learning dapat meningkatkan minat serta motivasi siswa atau mahasiswa dalam kegiatan pembelajaran (Khasan, 2009). Metode pembelajaran e- learning adalah sebuah metode yang mengembangkan kemampuan teknologi informasi dunia maya dalam proses pembelajaran (Munir, 2009). e-learning diperuntukkan sebagai upaya membentuk transformasi pembelajaran dalam wujud digitalisasi yang memanfaatkan teknologi internet. Penggunaan metode e-learning dalam proses pembelajaran membutuhkan keterampilan seseorang, oleh sebab itu proses pembelajaran menggunakan metode e-learning membutuhkan kemampuan literasi komputer baik oleh guru atau dosen maupun siswa atau mahasiswa (Mutiyasa (2006).

Saat ini dunia tengah dilanda wabah yang bernama Coronavirus disease (COVID-19) yang telah berstatus pandemi termasuk Indonesia. Pemerintah mengeluarkan kebijakan agar masyarakat tetap berada dirumah masing-masing guna memutus mata rantai penyebaran virus tersebut. Berbagai langkah dilakukan pemerintah dalam upaya mencegah penyebaran virus tersebut, yakni melalui Social Distancing dan saat ini berubah menjadi Physical Distancing.

Langkah-langkah pencegahan Covid 19 mempengaruhi semua segi kehidupan, tidak hanya dibidang kesehatan, transportasi, industri, dan juga pendidikan. Dengan adanya Social Distancing dan Physical Distancing kegiatan belajar mengajar dilaksanakan dirumah, sesuai dengan Surat Edaran yang 
dikeluarkan oleh Menteri Pendidikan dan Kebudayaan 36962/MPK.A/HK/2020 tanggal 17 Maret perihal Pembelajaran secara Daring dan Bekerja dari Rumah dalam rangka Pencegahan Penyebaran Covid 19. Instruksi menteri tentang kebijakan belajar dirumah juga diikuti oleh surat edaran dari Gubernur Riau dan Walikota Pekanbaru dan diikuti pula oleh surat edaran Rektor Universitas Riau No2/UN19/SE/2020 tanggal 15 Maret 2020 tentang Pencegahan Corona Virus Disease (Covid 19) di lingkungan Universitas Riau.

Di Fakultas Keguruan dan IImu Pendidikan, kegiatan perkuliahan melalui media online berdasarkan kepada Surat Edaran Dekan FKIP No. 1939/UN.19.5.1.1.5/TU/2020 dan diperpanjang dengan Surat Edaran Dekan No. 2207/UN.19.5.1.1.5/TU/2020 tanggal 31 Maret 2020. Karena situasi yang belum 'jelas', terhitung semenjak tanggal 17 s.d 30 April 2020 berdasarkan SK Kemenkes No. HK.01.07/MENKES/250/2020 tanggal 12 April 2020 telah pula diberlakukan Pembatasan Sosial Berskala Besar (PSBB) di Pekanbaru. Semua surat edaran ini berdampak pada proses belajar mengajar yang mengharuskan dosen dan mahasiswa mengganti proses pembelajaran menggunakan sistem daring (dalam jaringan) atau online, bahkan kegiatan ini akan terus berlangsung sampai bulan Mei 2020.

Pada minggu-minggu pertama proses pembelajaran daring atau online, disaat mahasiswa belum sepenuhnya diliburkan karena adanya Pembatasan Sosial Berskala Besar (PSBB), telah dilaksanakan wawancara informal dengan beberapa orang mahasiswa Jurusan Pendidikan IPS FKIP Universitas Riau, Salah satunya mahasiswa di Program Studi (Prodi) Pendidikan Pancasila dan Pendidikan Kewarganegaraan (PPKn) FKIP Universitas Riau tentang penggunaan sistem pembelajaran daring atau online oleh dosen-dosen. Berdasarkan hasil wawancara diperoleh informasi bahwa mahasiswa menemui berbagai hambatan ketika mengikuti kegiatan pembelajaran daring atau online ini. Diantara hambatan yang ditemui terkait dengan keterbatasan jaringan yang disebabkan lokasi keberadaan mahasiswa. Ternyata, sebahagian besar mahasiswa sudah berada di kampung halaman masing-masing sehingga akses internet kurang tersedia dan sulit dijangkau. Hambatan lainnya yang dihadapi mahasiswa adalah tentang 
tambahan biaya yang harus dikeluarkan mahasiswa untuk membeli kuota internet (Putra, Witri, \& Sari, 2020). Hambatan lain yang tak kalah pentingnya adalah pada proses pembelajaran daring atau online beberapa dosen cenderung hanya memberikan tugas saja tanpa memberikan penjelasan tentang topik atau materi yang diberikan.

Berdasarkan uraian diatas, maka penelitian ini menjadi suatu hal yang layak untuk diteliti lebih lanjut.

\section{METODE PENELITIAN}

Berdasarkan judul penelitian, yakni Analisis Pelaksanaan Pembelajaran Jarak Jauh Berbasis E-Learning Pada Masa Pandemi Covid-19 Mahasiswa Jurusan IPS FKIP Universitas Riau, maka pada penelitian ini populasinya adalah semua mahasiswa Jurusan Pendidikan IPS FKIP Universitas Riau. Mahasiswa Jurusan Pendidikan IPS terdiri dari tiga program studi: Pendidikan Sejarah, Pendidikan Pancasila dan Kewarganegaraan, dan Pendidikan Ekonomi. Melalui Random Sampling Technique telah dipilih sebanyak 15\% dari mahasiswa disetiap program studi sebagai sampel penelitian. Untuk jelasnya. Jumlah populasi dan sampel dapat dilihat pada table 1. Dengan demikian jumlah sampel penelitian ini adalah sebanyak 101 orang mahasiswa di Jurusan IPS FKIP Universitas Riau.

Tabel 1. Populasi dan Sampel

\begin{tabular}{|c|c|c|c|c|}
\hline \multirow[b]{2}{*}{ No } & \multirow[b]{2}{*}{ Program Studi } & \multicolumn{2}{|c|}{ Populasi } & \multirow[b]{2}{*}{ Sampel } \\
\hline & & Jumlah Kelas & $\begin{array}{c}\text { Jumlah } \\
\text { Mahasiswa }\end{array}$ & \\
\hline 1 & Pendidikan Sejarah & 6 kelas & 226 & 34 orang \\
\hline 2 & $\begin{array}{l}\text { Pendidikan Pancasila dan } \\
\text { Kewarganegaraan }\end{array}$ & 6 kelas & 216 & 33 Orang \\
\hline 3 & Pendidikan Ekonomi & 6 Kelas & 227 & 34 Orang \\
\hline
\end{tabular}

Jenis penelitian ini adalah penelitian deskriptif kualitatif. Data yang akan dikumpulkan adalah data ordinal, yang berasal dari hasil e-kuesioner (google form). Mahasiswa yang terpilih menjadi sampel penelitian diminta untuk 
memberikan respon terhadap kuesioner yang telah disusun berdasarkan kisi-kisi instrument. Data yang dikumpulkan berupa summative response scale, dengan menggunakan skala Likert yang dimodifikasi dengan 3 pilihan jawaban. Respon yang diberikan mahasiswa disusun berdasarkan 3 tingkatan Skala Likert: $1=\mathrm{Ya}$; 2= Tidak; 3 = Ragu-ragu. Data yang diperoleh lalu dianalisis melalui analisis statistik deskriptif persentase berdasarkan kisi kisi instrument.

Tabel 2. Kisi-kisi Instrumen Penelitian

\begin{tabular}{|l|l|}
\hline Variabel & Indikator \\
\hline Pembelajaran jarak jauh & Tujuan yang jelas \\
& Relevan dengan kebutuhan Mutu pendidikan \\
& Efisien dan Efektivitas Program \\
& Pemerataan dan perluasan kesempatan belajar \\
& Kemandirian \\
& Keterpaduan \\
& Kesinambungan \\
\hline
\end{tabular}

\section{HASIL DAN PEMBAHASAN}

\section{Hasil Penelitian}

Berdasarkan penelitian yang telah dilaksanakan tentang bentuk pelaksanaan kegiatan pembelajaran jarak jauh berbasis e-learning mahasiswa di Jurusan Pendidikan IPS FKIP Universitas Riau, maka di dapatkan data tentang bentuk kegiatan pembelajaran sebagai berikut.

\section{Tujuan Pembelajaran Yang Jelas}

Berdasarkan data penyebaran angket kepada mahasiswa berupa google form mengenai tujuan pembelajaran yang jelas pada proses pembelajaran jarak jauh, sebanyak $66,83 \%$ mahasiswa menyatakan tujuan pembelajaran di berikan secara jelas oleh dosen, $11,39 \%$ mahasiswa menyatakan tujuan pembelajaran tidak diberikan secara jelas dan sebanyak $21,78 \%$ dari total sampel menyatakan ragu-ragu. Data tersebut dapat dilihat pada tabel berikut: 
Tabel 3. Tujuan Pembelajaran Yang Jelas

\begin{tabular}{|c|c|c|c|c|}
\hline \multirow{2}{*}{ No } & \multicolumn{1}{|c|}{ Pernyataan } & \multicolumn{3}{|c|}{ Respon (\%) } \\
\cline { 3 - 5 } & \multicolumn{1}{|c|}{ Ya } & Tidak & $\begin{array}{c}\text { Ragu- } \\
\text { Ragu }\end{array}$ \\
\hline 1 & $\begin{array}{l}\text { Apakah dosen menyampaikan tujuan } \\
\text { pembelajaran pada setiap materi yang } \\
\text { diberikan }\end{array}$ & 70,29 & 11,89 & 17,82 \\
\hline 2 & $\begin{array}{l}\text { Apakah tujuan pembelajaran yang } \\
\text { disampaikan oleh dosen telah tercapai }\end{array}$ & 63,37 & 10,89 & 25,74 \\
\hline \multicolumn{2}{|l|}{ Skor Rata - Rata } & $66,83 \%$ & $11,39 \%$ & $21,78 \%$ \\
\hline
\end{tabular}

\section{Relevan Dengan Kebutuhan}

Berdasarkan data yang diperoleh dari sebaran angket kepada mahasiswa mengenai relevansi pembelajaran jarak jauh dengan kebutuhan kondisi saat ini, sebanyak 88,12\% mahasiswa menyatakan pembelajaran jarak jauh yang dilaksanakan saat ini relevan dengan kebutuhan, 5,44\% mahasiswa menyatakan tidak relevan dan sebanyak $6,44 \%$ dari total sampel menyatakan ragu-ragu. Data tersebut dapat dilihat pada tabel berikut:

Tabel 4. Relevan Dengan Kebutuhan

\begin{tabular}{|c|l|c|c|c|}
\hline \multirow{2}{*}{ No. } & \multicolumn{1}{|c|}{ Pernyataan } & \multicolumn{3}{|c|}{ Respon (\%) } \\
\cline { 3 - 5 } & \multicolumn{1}{|c|}{ Ya } & Tidak & $\begin{array}{c}\text { Ragu- } \\
\text { Ragu }\end{array}$ \\
\hline 1 & $\begin{array}{l}\text { Apakah pelaksanaan pembelajaran jarak } \\
\text { jauh yang dilaksanakan di Jurusan IPS }\end{array}$ & 84,16 & 10,89 & 4,95 \\
\hline $\begin{array}{l}\text { FKIP Universitas Riau terlaksana } \\
\text { dengan baik. }\end{array}$ & $\begin{array}{l}\text { Apakah pelaksanaan pembelajaran jarak } \\
\text { jauh yang dilaksanakan di Jurusan IPS FKIP } \\
\begin{array}{l}\text { Universitas Riau sesuai dengan kebutuhan } \\
\text { kondisi saat ini }\end{array}\end{array}$ & 92,08 & 0 & 7,92 \\
\hline Skor rata-raata & $88,12 \%$ & $5,44 \%$ & $6,44 \%$ \\
\hline
\end{tabular}

\section{Mutu Pendidikan}


TUNJUK AJAR: JURNAL PENELITIAN ILMU PENDIDIKAN

Volume 4, Nomor 1, Februari 2021

P-ISSN: 2615-062X

E-ISSN: 2622-3554

http://dx.doi.org/10.31258/ita.v4i1.26-42

Berdasarkan data tentang mutu pendidikan dalam pembelajaran jarak jauh yang dilaksanakan Jurusan FKIP Universitas Riau, sebanyak 61,72\% sampel pada penelitian ini menyatakan bahwa pembelajaran jarak jauh yang dilaksanakan selama pandemi covid-19 ini dapat meningkatkan mutu pendidikan, 14,19\% mahasiswa menyatakan tidak dan sebanyak $24,09 \%$ dari total sampel menyatakan ragu-ragu. Data tersebut dapat dilihat pada tabel berikut:

Tabel 5. Mutu Pendidikan

\begin{tabular}{|c|c|c|c|c|}
\hline \multirow{2}{*}{ No. } & \multicolumn{1}{|c|}{ Pernyataan } & \multicolumn{3}{|c|}{ Respon (\%) } \\
\cline { 4 - 5 } & $\begin{array}{l}\text { Apakah anda aktif dalam kegiatan } \\
\text { pembelajaran jarak jauh }\end{array}$ & 87,13 & 8,91 & 3,96 \\
\hline 2 & $\begin{array}{l}\text { Apakah dengan pelaksanaan pembelajaran } \\
\text { jarak jauh dapat meningkatkan mutu } \\
\text { Pendidikan }\end{array}$ & 61,39 & 11,88 & 26,73 \\
\hline 3 & $\begin{array}{l}\text { Apakah dengan pelaksanaan pembelajaran } \\
\text { jarak jauh dapat meningkatkan kompetensi } \\
\text { anda sebagai calon guru }\end{array}$ & 36,64 & 21,78 & 41,58 \\
\hline \multicolumn{2}{|c|}{ Skor Rata - Rata } & $61,72 \%$ & $14,19 \%$ & $24,09 \%$ \\
\hline
\end{tabular}

\section{Efisien dan Efektivitas Program}

Berdasarkan data sebaran angket tentang efisien dan efektivitas program dalam pembelajaran jarak jauh yang dilaksanakan Jurusan FKIP Universitas Riau, sebanyak 75,5\% sampel pada penelitian ini menyatakan bahwa pembelajaran jarak jauh yang dilaksanakan selama pandemi covid-19 ini efektif dan efisien, $13,36 \%$ mahasiswa menyatakan tidak dan sebanyak $11,14 \%$ dari total sampel menyatakan ragu-ragu. Data tersebut dapat dilihat pada tabel berikut:

Tabel 6. Efisien dan Efektifitas Program

\begin{tabular}{|c|c|c|c|c|}
\hline \multirow{2}{*}{ No } & Pernyataan & \multicolumn{3}{|c|}{ Respon (\%) } \\
\cline { 3 - 5 } & $\begin{array}{l}\text { Apakah pembelajaran jarak jauh yang diberikan } \\
\text { dosen kepada Anda mudah dipelajari }\end{array}$ & Tidak & $\begin{array}{c}\text { Ragu- } \\
\text { Ragu }\end{array}$ \\
\hline 2 & $\begin{array}{l}\text { Apakah pembelajaran jarak jauh yang } \\
\text { dibawakan dosen dapat diakses dengan mudah }\end{array}$ & 90,1 & 18,81 & 5,94 \\
\hline
\end{tabular}


TUNJUK AJAR: JURNAL PENELITIAN ILMU PENDIDIKAN

Volume 4, Nomor 1, Februari 2021

P-ISSN: 2615-062X

E-ISSN: 2622-3554

http://dx.doi.org/10.31258/ita.v4i1.26-42

\begin{tabular}{|c|l|r|r|r|}
\hline 3 & $\begin{array}{l}\text { Apakah interaksi antara dosen dan mahasiswa } \\
\text { dalam pembelajaran jarak jauh terlaksana } \\
\text { dengan baik }\end{array}$ & 76,24 & 17,82 & 5,94 \\
\hline 4 & $\begin{array}{l}\text { Apakah anda kesulitan dalam memahami materi } \\
\text { yang dijelaskan melalui pembelajaran jarak jauh }\end{array}$ & 60,4 & 16,83 & 22,77 \\
\hline Skor Rata - Rata & $75,5 \%$ & $13,36 \%$ & $11,14 \%$ \\
\hline
\end{tabular}

\section{Pemerataan dan Perluasan Kesempatan Belajar}

Berdasarkan data sebaran angket tentang efisien dan efektivitas program dalam pembelajaran jarak jauh yang dilaksanakan Jurusan FKIP Universitas Riau, sebanyak 79,21\% sampel pada penelitian ini menyatakan bahwa pembelajaran jarak jauh yang dilaksanakan selama pandemi covid-19 ini mengedepankan pemerataan dan perluasan kesempatan belajar bagi mahasiswa, 10,89\% mahasiswa menyatakan tidak dan sebanyak 9,9\% dari total sampel menyatakan ragu-ragu. Data tersebut dapat dilihat pada tabel berikut:

Tabel 7. Pemerataan dan Perluasan Kesempatan Belajar

\begin{tabular}{|c|c|c|c|c|}
\hline \multirow{2}{*}{ No. } & \multirow{2}{*}{ Pernyataan } & \multicolumn{3}{|c|}{ Respon (\%) } \\
\hline & & Ya & Tidak & $\begin{array}{l}\text { Ragu- } \\
\text { Ragu }\end{array}$ \\
\hline 1 & $\begin{array}{l}\text { Apakah dosen selalu berusaha } \\
\text { memberikan motivasi kepada mahasiswa } \\
\text { untuk } \\
\text { menyelesaikan tugas yang diberikan }\end{array}$ & 76,24 & 10,89 & 12,87 \\
\hline 2 & $\begin{array}{l}\text { Apakah dosen memberikan waktu yang } \\
\text { cukup kepada mahasiswa untuk } \\
\text { Menyelesaikan tugas pembelajaran }\end{array}$ & 82,18 & 10,89 & 6,93 \\
\hline & Skor Rata - Rata & $79,21 \%$ & $10,89 \%$ & $9,9 \%$ \\
\hline
\end{tabular}

\section{Kemandirian}

Berdasarkan data sebaran angket tentang kemandirian dalam pembelajaran jarak jauh yang dilaksanakan Jurusan FKIP Universitas Riau, sebanyak 91,09\% sampel pada penelitian ini menyatakan bahwa pembelajaran jarak jauh yang dilaksanakan selama pandemi covid-19 ini dapat menumbuhkan rasa kemandirian 
TUNJUK AJAR: JURNAL PENELITIAN ILMU PENDIDIKAN

Volume 4, Nomor 1, Februari 2021

P-ISSN: 2615-062X

E-ISSN: 2622-3554

http://dx.doi.org/10.31258/ita.v4i1.26-42

dalam pemahaman terhadap materi pelajaran sedangkan sebanyak 9,91\% menyatakan ragu-ragu. Data tersebut dapat dilihat pada tabel berikut:

Tabel 8. Kemandirian

\begin{tabular}{|c|c|c|c|c|}
\hline \multirow{2}{*}{ No } & \multicolumn{1}{|c|}{ Pernyataan } & \multicolumn{3}{|c|}{ Respon (\%) } \\
\cline { 3 - 5 } & $\begin{array}{l}\text { Apakah dengan pelaksanaan pembelajaran } \\
\text { jarak jauh dapat menumbuhkan rasa } \\
\text { kemandirian anda dalam mempelajari hal- } \\
\text { hal baru }\end{array}$ & 91,09 & 0 & Tidak \\
\hline Skor Rata - Rata & $91,09 \%$ & $0 \%$ & $9,91 \%$ \\
\hline
\end{tabular}

\section{Keterpaduan}

Berdasarkan data sebaran angket tentang keterpaduan dalam pembelajaran jarak jauh yang dilaksanakan Jurusan FKIP Universitas Riau, sebanyak 78,22\% sampel pada penelitian ini menyatakan bahwa terdapat nilai- nilai keterpaduan dalam pelaksanaan pembelajaran jarak jauh, sebanyak 3,96\% menyatakan tidak dan sebanyak $17,82 \%$ mahasiswa menyatakan ragu-ragu. Data tersebut dapat dilihat pada tabel berikut:

Tabel 9. Keterpaduan

\begin{tabular}{|c|c|c|c|c|}
\hline \multirow{2}{*}{ No } & Pernyataan & \multicolumn{3}{|c|}{ Respon (\%) } \\
\cline { 3 - 5 } & & Ya & Tidak & $\begin{array}{c}\text { Ragu- } \\
\text { Ragu }\end{array}$ \\
\hline \multirow{2}{*}{1} & $\begin{array}{l}\text { Apakah pembelajaran jarak jauh dapat di } \\
\text { terapkan dengan baik dalam berbagai } \\
\text { bidang matakuliah }\end{array}$ & 78,22 & 3,96 & 17,82 \\
\hline \multicolumn{2}{|c|}{ Skor Rata - Rata } & $78,22 \%$ & $3,96 \%$ & $17,82 \%$ \\
\hline
\end{tabular}




\section{Kesinambungan}

Berdasarkan data sebaran angket tentang keterpaduan dalam pembelajaran jarak jauh yang dilaksanakan Jurusan FKIP Universitas Riau, sebanyak 68,81\% sampel pada penelitian ini menyatakan bahwa terdapat nilai- nilai kesinambungan dalam pelaksanaan pembelajaran jarak jauh, sebanyak 17,32\% menyatakan tidak dan sebanyak $13,87 \%$ mahasiswa menyatakan ragu- ragu. Data tersebut dapat dilihat pada tabel berikut:

Tabel 10. Kesinambungan

\begin{tabular}{|c|c|c|c|c|}
\hline \multirow{2}{*}{ No } & Pernyataan & \multicolumn{3}{c|}{ Respon (\%) } \\
\cline { 3 - 5 } & Ya & Tidak & $\begin{array}{c}\text { Ragu- } \\
\text { Ragu }\end{array}$ \\
\hline 1 & $\begin{array}{l}\text { Apakah dosen melakukan pembimbingan } \\
\text { dalam menyelesaikan penugasan yang } \\
\text { diberikan }\end{array}$ & 60,40 & 23,76 & 15,84 \\
\hline 2 & $\begin{array}{l}\text { Apakah dosen memberikan motivasi } \\
\text { kepada anda untuk menyelesaikan } \\
\text { penugasan yang diberikan }\end{array}$ & 77,23 & 10,89 & 11,88 \\
\hline \multicolumn{2}{|c|}{\begin{tabular}{c} 
Skor Rata - Rata \\
\hline
\end{tabular}} \\
\hline
\end{tabular}

\section{Jenis Aplikasi Pembelajaran Online Yang Digunakan}

Berdasarkan data penyebaran angket kepada mahasiswa berupa google form mengenai jenis aplikasi pembelajaran olnlie yang dilaksanakan antara mahasiswa dengan dosen pengampu matakuliah, sebanyak 35\% proses pembelajaran online yang dilaksanakan adalah menggunakan aplikasi pembelajaran Google Classroom, Sebanyak 35\% proses pembelajaran online yang dilaksanakan adalah menggunakan aplikasi WhatsApp grup, sebanyak 15\% proses pembelajaran dilaksanakan menggunakan aplikasi Zoom Meeting, sebanyak $10 \%$ proses pembelajaran jarak jauh ini menggunakan aplikasi Google Meet, sebanyak $4 \%$ proses pembelajaran jarak jauh menggunakan aplikasi Jitsi Meet dan sebanyak 1\% menggunakan aplikasi Edmodo dalam proses pembelajaran. Data tentang jenis aplikasi pembelajaran online yang dilakukan 
TUNJUK AJAR: JURNAL PENELITIAN ILMU PENDIDIKAN

Volume 4, Nomor 1, Februari 2021

P-ISSN: 2615-062X

E-ISSN: 2622-3554

http://dx.doi.org/10.31258/ita.v4i1.26-42

antara dosen dengan mahasiswa Jurusan Pendidikan IPS FKIP Universitas Riau dapat dilihat pada berikut:

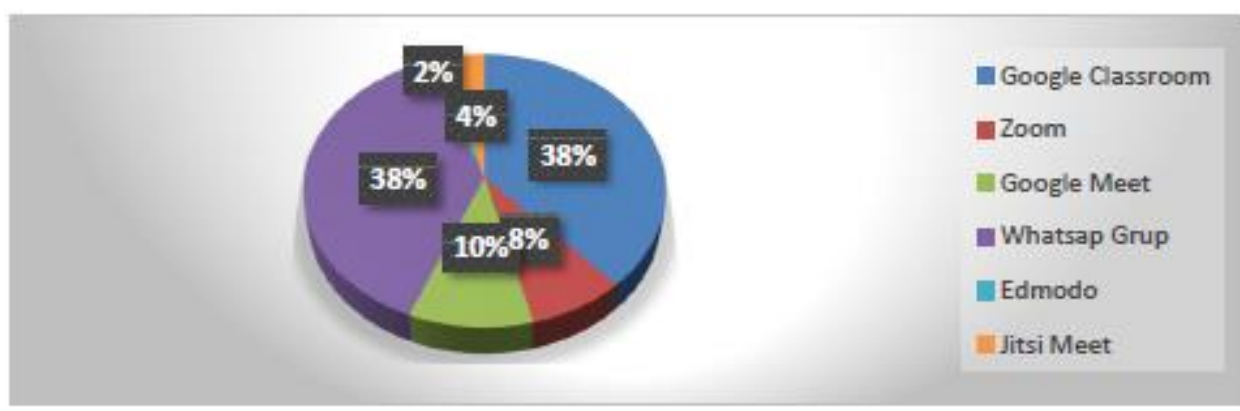

Gambar 1. Jenis Aplikasi Pembelajaran Online yang Digunakan

\section{Jenis Pembelajaran Yang Disukai Saat Pembelajaran Jarak Jauh}

Berdasarkan data penyebaran angket kepada mahasiswa berupa google form mengenai jenis pembelajaran yang disukai saat pembelajaran jarak jauh, sebanyak $40 \%$ menyukai pembelajaran jarak jauh dengan menggunakan media aplikasi Google Classroom, sebanyak 40\% jawaban mahasiswa menyukai pembelajaran jarak jauh dengan menggunakan media aplikasi WhatsApp Grup, sebanyak $11 \%$ mahasiswa lebih memilih menyukai jenis pembelajaran jarak jauh dengan menggunakan media aplikasi Google Meet, Sedangkan 9\% mahasiswa menyukai pembelajaran jarak jauh dengan menggunakan media aplikasi Zoom Meeting. Data jenis pembelajaran jarak jauh yang disukai mahasiswa Jurusan Pendidikan IPS FKIP Universitas Riau dapat dilihat pada gambar berikut:

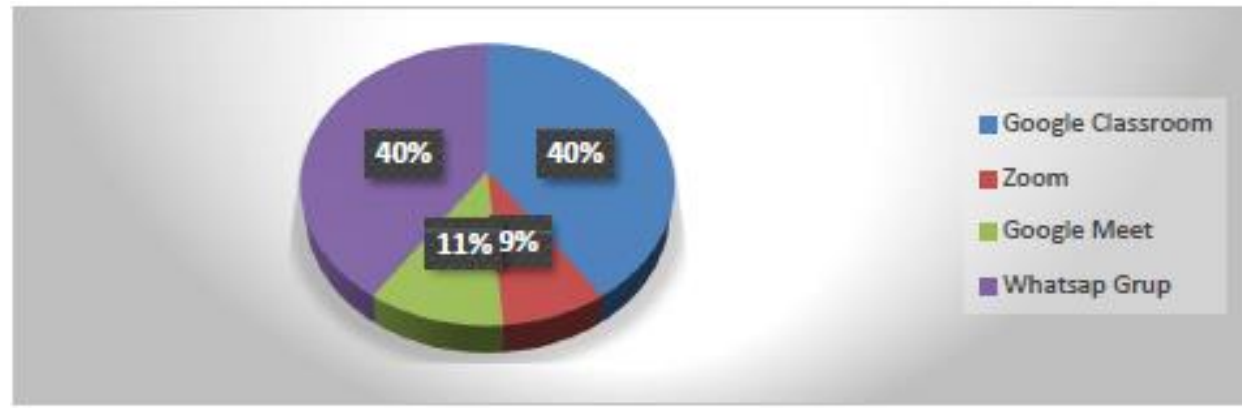

Gambar 2. Jenis Aplikasi Pembelajaran Yang Disukai Saat Pembelajaran Jarak Jauh

Kendala Yang Dihadapi Selama Pembelajaran Jarak Jauh 
Berdasarkan data penyebaran angket kepada mahasiswa berupa google form mengenai kendala yang dihadapi mahasiswa selama proses pembelajaran jarak jauh, sebanyak $43 \%$ menjawab bahwa kendala dalam proses pembelajaran jarak jauh adalah ketersediaan kuota, sebanyak 33\% kendala yang dihadapi adalah akses jaringan internet yang terbatas, sebanyak $15 \%$ menjawab bahwa ketersediaan perangkat menjadi penyebab terkendalanya proses pembelajaran jarak jauh, sedangkan sebanyak 9\% penyebab terkendalanya proses pembelajaran adalah terkait waktu. Data tentang kendala yang dihadapi mahasiswa Jurusan Pendidikan IPS FKIP Universitas Riau dalam pelaksanan pembelajaran jarak jauh dapat diliah pada gambar berikut

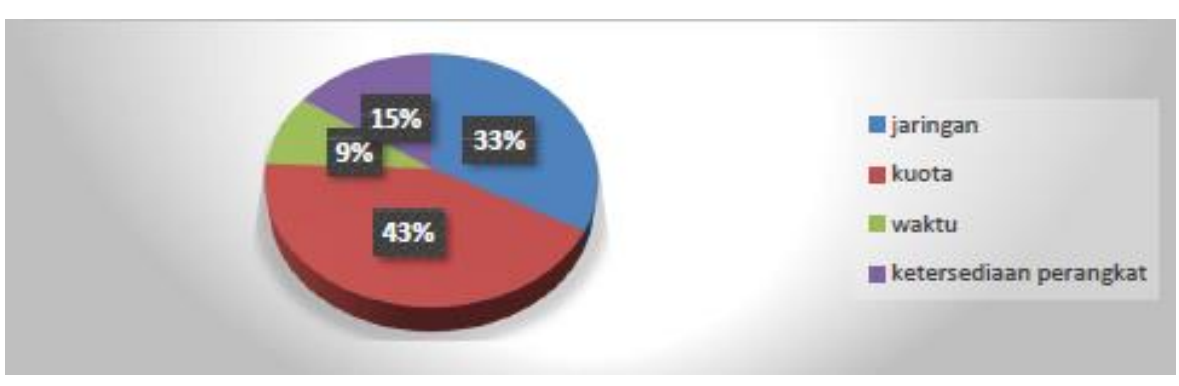

Gambar 3. Kendala Yang Dihadapi Selama Pembelajaran Jarak Jauh

\section{Pembahasan Peneltian}

Hasil analisis data memperlihatkan bahwa sebesar $66,83 \%$ dari total sampel pada penelitian ini menyatakan bahwa tujuan pembelajaran sangat jelas dalam kegiatan pembelajaran jarak jauh, hal ini sejalan dengan jawaban mahasiswa yakni sebanyak $88,12 \%$ mengatakan bahwa kegiatan pembelajaran jarak jauh yang dilaksanakan saat ini sesuai dengan kebutuhan dikarenakan situasi dan kondisi pandemi covid-19 saat ini. Namun, dalam melaksanakan pembelajaran jarak jauh tentu haruslah tetap menjaga mutu pendidikan itu sendiri. Berdasarkan skor rata-rata yang di peroleh, sebanyak $61,72 \%$ sampel menyatakan bahwa kegiatan pembelajaran jarak jauh yang diselenggarakan di Jurusan IPS FKIP Universitas Riau dapat meningkatkan mutu pendidikan. Sebab, sebanyak 75,5\% mahasiswa menyatakan bahwa kegiatan pembelajaran jarak jauh ini sangat efisien dan efektif. Sebanyak $79,21 \%$ mahasiswa menyatakan, dalam 
pembelajaran jarak jauh berbasis e-learning yang diselenggarakan saat ini mengedepankan pemerataan dan perluasan kesempatan bagi mahasiswa sehingga dapat menumbuhkan rasa kemandirian dalam belajar, karena 91,09\% mahasiswa menyatakan bahwa dengan pelaksanaan kegiatan pembelajaran jarak jauh ini, setiap siswa dituntut untuk lebih kreatif dalam menyelesaikan setiap materi dan penugasan yang diberikan oleh dosen sehingga menumbuhkan rasa kemandirian bagi mahasiswa itu sendiri. Pembelajaran jarak jauh yang di selenggarakan di Jurusan IPS FKIP Universitas Riau hendaklah dapat diterapkan di setiap mata kuliah. Berdasarkan skor rata-rata terkait tingkat keterpaduan pelaksanaan kegiatan pembelajaran jarak jauh, sebesar 78,22\% mahasiswa menyatakan bahwa penggunaan media e-learning dalam pembelajaran jarak jauh ini dapat dilaksanakan dengan baik walaupun dengan materi perkuliahan yang berbeda, sebab sebesar $68,81 \%$ mahasiswa menyatakan bahwa dosen selalu memberikan pendampingan dan motivasi kepada mahasiswa dalam menyelesaikan setiap materi dan penugasan yang diberikan sehingga kegiatan pembelajaran jarak jauh dapat dilaksanakan secara berkesinambungan.

Namun dalam kegiatan pembelajaran jarak jauh ini tentu terdapat pula permasalahan atau pun kendala yang di hadapi, seperti keterbatasan kuota, keterbatasan jaringan internet, keterbatasan perangkat pendukung pembelajaran jarak jauh dan lain sebagainya. Masalah ini sebenarnya bukanlah masalah yang dihadapi oleh mahasiswa Jurusan Pendidikan IPS FKIP Universitas Riau saja, melainkan juga masalah yang terjadi di berbagai wilayah di Indonesia bahkan di luar negeri seperti Tanzania (Alcuin, 2011) dan Kazakhstan (Aliya Mustafina, 2016).

Hal ini sesuai pendapat Teo, yang mengatakan jika keberhasilan belajar peserta didik atau dalam hal ini adalah mahasiswa dengan memanfaatkan perangkat komputer akan sangat tergantung pada sikap pengajar dan kemauan pengajar itu sendiri untuk 'merangkul' teknologi (Teo, 2006). Sikap positif pengajar yang dalam hal ini adalah dosen terhadap penggunaan perangkat komputer khususnya yang berbasis e-learning dapat memberikan wawasan yang berguna terhadap penerimaan serta penggunaan teknologi dalam pengajaran dan 
pembelajaran mereka. Pendapat senada dikemukakan oleh Huang \& Liaw, dimana diantara banyak faktor-faktor yang mempengaruhi keberhasilan penggunaan komputer adalah sikap pengajar terhadap komputer (Huang \& Liaw, 2005). Pengajar yang dalam hal ini adalah dosen harus dapat bertindak sebagai agen perubahan dalam hubungan antara teknologi dan mahasiswa (Kadel, 2005).

Secara umum diyakini bahwa seorang dosen yang mempunyai sikap positif terhadap TIK lebih termotivasi untuk mengintegrasikannya ke dalam kegiatan pembelajarannya (Albirini, 2006; Cavas et al, 2009). Beberapa peneliti menjelaskan bahwa sikap terhadap teknologi dapat bervariasi dari sangat positif hingga sangat negatif tergantung pada kombinasi berbagai faktor yang dapat mempengaruhi sikap. Efektifitas, pemahaman e-learning, jenis kelamin dan usia merupakan faktor-faktor penting (Aliya Mustafina, 2016). Pernyataan serupa dikemukakan), sikap institusional yang positif terhadap perkembangan TIK khususnya e-learning berkaitan dengan efektifitas pembelajaran yang akan di sampaikan oleh dosen (Yukiko Yamamoto and Shinobu Yamaguchi, 2016).

Permasalahan yang juga penting untuk dicarikan penyelesaiannya adalah kurangnya fasilitas pendukung bagi terlaksananya pembelajaran jarak jauh oleh mahasiswa Jurusan IPS FKIP Universitas Riau diantaranya adalah kurangnya ketersediaan perangkat yang dialami oleh sebanyak $15 \%$ mahasiswa dari total sampel penelitian ini. Hal ini pun tidak hanya dialami oleh mahasiswa di Jurusan Pendidikan IPS FKIP Universitas Riau saja, tetapi juga terjadi di Tanzania (Nyarusy, 2006).

Walaupun mahasiswa menghadapi berbagai kendala dalam proses pembelajaran jarak jauh, mereka menyatakan bahwa banyak manfaat yang dapat diperoleh melalui pemanfaatan e-learning dalam kegiatan pembelajaran, di antaranya adalah dari segi pemanfaatan waktu. Dengan menggunakan media pembelajaran interaktif, mahasiswa dapat menjelaskan konsep dan materi pelajaran lebih cepat. Dosen dapat pula memvisualisasikan materi pembelajaran yang tidak mungkin dihadirkan di kelas melalui video atau gambar-gambar yang sudah di download dari internet (Afamasaga, 2008; Dipuja, 2020). Dosen juga memanfaatkan fasilitas e-learning untuk pengumpulan tugas, sehingga kegiatan 
pembelajaran jarak jauh dapat lebih difokuskan kepada kegiatan lain untuk mengungkapkan temuannya bahwa internet banyak digunakan oleh para pengajar yang dalam hal ini adalah dosen untuk mencari informasi sebelum mengajar (Mulyani, Alpusari, \& Putra, 2021). Akhirnya dapat dikatakan bahwa keberhasilan penggunaan TIK dalam pembelajaran berbasis e-learning dalam kegiatan pembelajaran jarak jauh sangat terkait dengan sikap yang dikembangkan Dosen terhadap komputer (Šorgo, 2010) dan sikap positif atau negatif seorang Dosen terhadap komputer juga ditentukan oleh bentuk pembelajaran berbasis e-learning yang akan diberikan kepada mahasiswa tersebut.

\section{SIMPULAN}

Bentuk kegiatan pembelajaran jarak jauh yang dilaksanakan di jurusan IPS FKIP Universitas Riau mengacu kepada indikator pembelajaran jarak jauh, yakni: tujuan pembelajaran yang jelas, relevan dengan kebutuhan, mutu Pendidikan, efisien dan efektivitas program, pemerataan dan perluasan kesempatan belajar, kemandirian, keterpaduan dan kesinambungan. Berdasarkan hasi penelitian memperlihatkan bahwa sebesar $66,83 \%$ mahasiswa menyatakan bahwa tujuan pembelajaran sangat jelas, sebanyak $88,12 \%$ mengatakan bahwa kegiatan pembelajaran jarak jauh yang dilaksanakan saat ini sesuai dengan kebutuhan dikarenakan situasi dan kondisi pandemi covid-19 saat ini. Sebanyak 61,72\% sampel menyatakan bahwa kegiatan pembelajaran jarak jauh yang diselenggarakan di Jurusan IPS FKIP Universitas Riau dapat meningkatkan mutu Pendidikan, sebanyak $75,5 \%$ mahasiswa menyatakan bahwa kegiatan pembelajaran jarak jauh ini sangat efisien dan efektif, sebanyak 79,21\% mahasiswa menyatakan, dalam pembelajaran jarak jauh berbasis e-learning yang diselenggarakan saat ini mengedepankan pemerataan dan perluasan kesempatan belajar, sebanyak 91,09\% mahasiswa menyatakan bahwa dengan pelaksanaan kegiatan pembelajaran jarak jauh ini, setiap siswa dituntut untuk lebih kreatif dalam menyelesaikan setiap materi dan penugasan yang diberikan oleh dosen sehingga menumbuhkan rasa kemandirian bagi mahasiswa itu sendiri, sebesar 
TUNJUK AJAR: JURNAL PENELITIAN ILMU PENDIDIKAN

Volume 4, Nomor 1, Februari 2021

P-ISSN: 2615-062X

E-ISSN: 2622-3554

http://dx.doi.org/10.31258/ita.v4i1.26-42

78,22\% mahasiswa menyatakan bahwa penggunaan media e-learning dalam pembelajaran jarak jauh ini dapat dilaksanakan dengan baik walaupun dengan materi perkuliahan yang berbeda, sebab sebesar $68,81 \%$ mahasiswa menyatakan bahwa dosen selalu memberikan pendampingan dan motivasi kepada mahasiswa dalam menyelesaikan setiap materi dan penugasan yang diberikan sehingga kegiatan pembelajaran jarak jauh dapat dilaksanakan secara berkesinambungan.

\section{DAFTAR PUSTAKA}

Afamasaga, F. T. (2008). Teacher Perceptions of Information Communication Technology in a secondary school in Samoa. Unpublished Master Thesis. Victoria University of Wellington.

Albirini, A. (2006). Teachers' attitudes toward information and communication technologies: the case of Syrian EFL teachers. Computers \& Education 47: 373-398

Alcuin. (2011). International Journal of Education and Development using Information and Communication Technology (IJEDICT). 7(3): 36-49.

Aliya Mustafina. (2016). Teachers' Attitudes toward Technology integration in a Kazakhstani Secondary School. International Journal of Research in Education and Science. 2(2): 322-332.

Dipuja, D. A. (2020). Persepsi Mahasiswa terhadap Video Monolog Sebagai Alternatif Tugas dalam Pembelajaran Daring. Tunjuk Ajar: Jurnal Penelitian IImu Pendidikan, 3(1), 114-129.

Huang, H. M., Liaw, S. S., (2005). Exploring User's Attitudes andlintentions toward the Web as a Survey Tool. Computers in Human Behavior. 21(5) :729-743.

Kadel, R. (2005). How Teacher Attitude affect Technology. Learning and Leading with Technology. 39(5): 34-36.

Khasan, dkk. (2009). Efektifitas Penggunaan Metode Pembelajaran Elearning Berbasis Browser Based Training terhadap Prestasi Belajar Siswa pada Kompetensi Pemeliharaan/Servis Transmisi Manual dan Komponen. Jurnal PTM, 9(1), hlm. 40 
Mulyani, E. A., Alpusari, M., \& Putra, E. D. (2021). The Effect of Learning Facilities and Family Environment on Motivation to Learn of Prospective Elementary Teacher Education on Online Learning. Journal of Teaching and Learning in Elementary Education, 4(1), 86-94.

Munir. (2009). Pembelajaran Jarak Jauh: Berbasis Teknologi Informasi dan Komunikasi, Bandung, CV. ALVABETA.

Murtiyasa, B. (2006). Pemanfaatan Teknologi Informasi dan Komunikasi untuk Meningkatkan Kualitas Pembelajaran Matematika, Pidato Pengukuhan Guru Besar Pendidikan Matematika tanggal 19 September. Surakarta: Universitas Muhammadiyah Surakarta.

Nyarusy, F. (2006). The Effectiveness of ICT Application in Enhancing Teaching and Learning Processes in Private Secondary Schools In Tanzania.Unpublished Master Thesis. University of Dares Salaam

Putra, Z. H., Witri, G., \& Sari, I. K. (2020). Prospective elementary teachers' perspectives on online mathematics learning during coronavirus outbreak. Journal of Physics: Conference Series 1655 (1), 012057.

Putri, F. Z., Putra, Z. H., \& Munjiatun, M. (2021). Pengembangan Media Kartu Domino Materi Pecahan untuk Belajar Mandiri Siswa Kelas IV SDN 147 Pekanbaru Di Masa New Normal. Jurnal IImiah Aquinas, 4(1), 113-126.

Sorgo, A., Verckovnik, T. V., Kocijancic, S. (2010). Information and Communication Technologies (ICT) in Biology Teaching in Slovenian Secondary Schools. Eurasia Journal of Mathematics, Science \& Technology Education. 6(1): 37-46.

Teo, T. (2006). Attitudes toward computers: A study of post-secondary students in Singapore. Interactive Learning Environments, 14(1): 17-24.

Yamamoto, Y., Yamaguchi. S. (2016). A study on teacher's Self-efficacy for Promoting ICT Integrated Education in Primary Schools in Mongolia. Journal of International Cooperation in Education. 18(2): 1-15. 